\title{
Auto Regressive Distributed Lag Model for Crude Oil (Brent) and Crude Oil (WTI)
}

\author{
Dhaval Maheta
}

\begin{abstract}
It has been found through various literatures that Crude Oil (Brent) and Crude Oil (WTI) series moves in close proximity. This paper tries to examine the causality relationship between Crude Oil(WTI) and Crude Oil(Brent). In absence of cointegration between the two series Auto Regressive Distributed Lag Model was used.
\end{abstract}

Keywords: Crude Brent Oil, West Texas Intermediate (WTI) Oil.

\section{INTRODUCTION}

Crude Oil, commonly known as petroleum, is a liquid found in the inner crust of Earth. It includes organic compounds, hydrocarbons and metals. Due to the different usage of crude oil in industry, they are traded on different bourses based on its grade, delivery and money terms. Crude oil can be classified into two broad categories. Crude Oil (Brent) and Crude Oil (Brent). Crude Oil is the barometer of world's economy. Fluctuation in Crude Oil can give rise to unstable economy in any country. It has been found that price of Brent Crude Oil and WTI Crude Oil are correlated with each other. Shell UK Exploration and Production have policy to name all its fields with bird names. So Brent is a goose bird. It is also acronym of Broom, Rannoch, Etive, Ness and Tarbert. They are oil fields formed in layer of B-R-E-N-T.

\section{LITERATURE REVIEW}

The international oil prices are affected by prices of Crude (WTI) and Crude (Brent). The prices of WTI and Brent according to Chen, Huang et al. are used an indicator for any business decisions and government policies. Adelman and Watkins (1997) and Smith (2004) had raised strong objections for considering oil in Reserves of any country. Kilian (2014) observed that Brent and Crude started diverging from each other after 2014. An econometric relationship was tried to establish between natural gas price and Crude (WTI) Price by Jose and Joutz (2006). In the recent years it has been observed that correlation between natural gas prices and crude oil price does not exist anymore according to the cointegration test applied by Ramberg and Parsons (2012).

\section{RESEARCH METHDOLOGY}

\subsection{Objective of the study}

The primary objective of this study is to investigate the relationship which exists between Crude Brent Oil and Crude West Texas Intermediate.

\footnotetext{
Revised Manuscript Received on November 22, 2018.

* Correspondence Author

Dr. Dhaval Maheta, Assistant Professor, Department of Business and Industrial Management, Surat, India.
}

\subsection{Period of the study}

To carry out above mentioned study data of Crude Brent Oil and Crude West Texas Intermediate (WTI) oil is collected from $1^{\text {st }}$ February, 2009 to $1^{\text {st }}$ February, 2019.

\subsection{Sources of data}

For the purpose of the above study data has been collected from Macro Trends Official Website (www.macrotrends.net).

\subsection{Hypothesis for the study}

The hypothesis considered for this study is:

$\mathrm{H}_{0}$ : There does not exists any relationship between Crude (Brent) and Crude (WTI) Oil Price.

$\mathrm{H}_{1}$ : There exists relationship between Crude (Brent) and Crude (WTI) Oil Price.

\subsection{Econometric Models}

\section{Granger Causality Test}

The basic condition in Granger causality is that both the series should be stationary. By using different lags of $X_{t}$ and $\mathrm{Y}_{\mathrm{t}}$ both we try to establish direction in the Granger causality test which identifies dependent and independent variable.

$$
\begin{aligned}
& y_{t}=a_{1}+\sum_{i=1}^{n} \beta_{i} x_{t-i}+\sum_{j=1}^{m} \gamma_{j} y_{t-j}+e_{1 t} \\
& x_{t}=a_{2}+\sum_{i=1}^{n} \theta_{i} x_{t-i}+\sum_{j=1}^{m} \delta_{j} y_{t-j}+e_{2 t}
\end{aligned}
$$

where it is assumed that $\mathrm{e}_{1 \mathrm{t}}$ and $\mathrm{e}_{2 \mathrm{t}}$ does not have correlation between them.

Auto Regressive Distributed Lag (ARDL) Model The ARDL model given below has lags of Y and X

$$
Y_{t}=a+\beta_{1} X_{t}+\beta_{1} X_{t-1}+\beta_{3} Y_{t-1}+\varepsilon_{y t}
$$




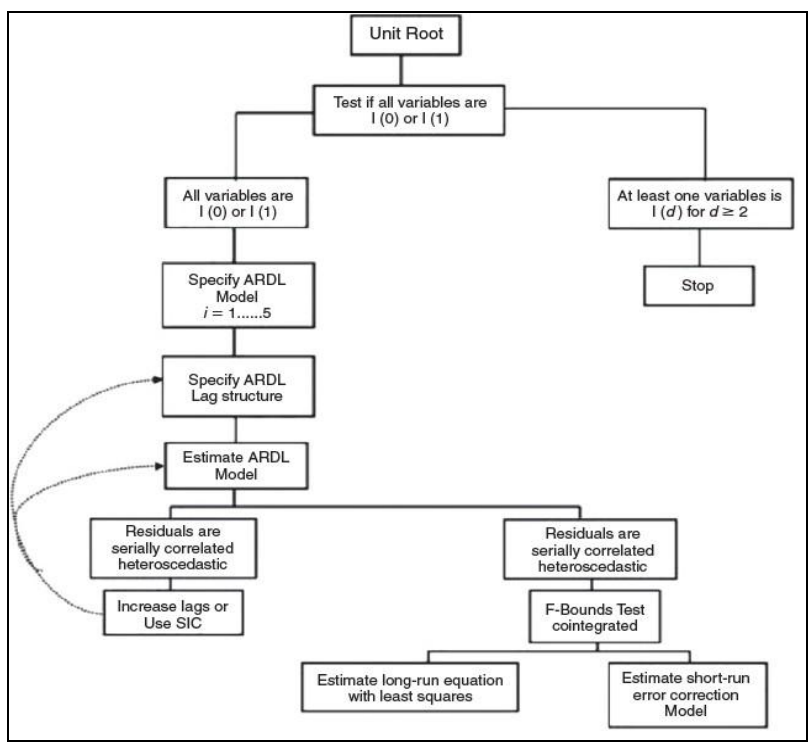

FIGURE 1: STEPS FOR ARDL MODEL

\section{RESULTS AND DISCUSSIONS}

In Appendix, Figure 2 it can be seen that Crude (Brent) and Crude (WTI) prices are moving together. Table 1 gives descriptive statistics of Brent Oil and WTI Oil. From Table 1, it can be seen that mean of WTI and Brent is 78.98 and 85.24 respectively. As the minimum and maximum range of both these variable is too dispersing, the mean value is not able to give the actual picture for all variables in Table 1. As range is bigger for both the series, the standard deviation of each variable in Table 1 is too high. Standard deviation of WTI and Brent is 24.264 and 27.601 respectively. All the variables in Table 1 shows positive skewness which means that right tail is longer than left and thus are positively skewed. To measure the extent of peak of data, statistical measure Kurtosis is used. A kurtosis value $>3$ means data is leptokurtic which is sharp peaked data and is thus having heavy tail near mean. A kurtosis value $<3$ is for platykurtic data which have flat top and for normal distribution kurtosis value will be 3 . Looking at the table 1 , kurtosis values of WTI and Brent is 2.0715 and 1.652 respectively which means both variables are platykurtic. The $\mathrm{p}$-value for Jarque Bera statistics is 0.1148 and 0.1090 for WTI and Brent Oil series. So we can say that WTI is normally distributed while Brent Oil series is not normally distributed. In Figure 3 and Table 3 , it can be seen that there is a high degree of correlation between first difference of Brent Oil series and WTI Oils series. To establish causality between Brent and WTI Oil series we run Granger Causality Test. In Table 4, we fail to reject null hypothesis which means that DWTI (first difference of WTI) does not Granger Cause DBRENT (first difference of Brent) and vice versa. It can be seen that though there is correlation between these two series but as causality is absent we cannot use any Cointegration Models. So we employ Auto Regressive Distributed Lag (ARDL) model. In Table 5, ARDL model which is identified is $\operatorname{ARDL}(1,1)$ according to AIC Criterion which will be formally tested.

According to Table 6, the model which is considered for this series is:

BRENT $=0.936 \mathrm{WTI}-0.937 \mathrm{WTI}_{(-1)}$
The coefficient of WTI is negative and significant which means that it is correcting the system at the rate of $93.7 \%$ which is very good. Moreover by using this equation WTI is able to explain $87.2 \%$ variance in BRENT. Equation (1) is tested for Serial Correlation Test, Heterosekdasticity Test and Normality Test. From Table 7, it can be seen that residuals are not serially correlated, residuals are homoscedastic and residuals are normally distributed. It is necessary to run Bound Test for the variable $\mathrm{WTI}_{(-1)}$. The null hypothesis is that the coefficient of $\mathrm{WTI}_{(-1)}$ is zero or in other words long run association does not exist. As the p-value is 0.0211 which is less than 0.05 so we reject null hypothesis which means that long run association exists between Brent and WTI. From Figure 4, it can be seen that blue line is between two red lines and so above mentioned model is stable. In Figure 5, it can be seen that blue line is between the two red lines so this model is able to forecast BRENT based on WTI. The test considered for good forecasting is Theil's coefficient. Theil's Inequality Coefficient is 0.0544 which is less than 1 , it means that model used for forecasting is better than guessing. Root Mean Squared Error is 1.6366 which is also very less so our model is good.

\section{CONCLUSIONS}

It can be concluded that though Brent Oil and WTI Oil series are highly correlated but there is no cointegration between these two series. In this scenario we cannot use Error Correction Mechanism (ECM) model so we employed Auto Regressive Distributed Lag Model (ARDL). The ARDL model of Brent Oil Series and WTI Oil Series is also good for forecasting. So we can say that there exists a short run as well as long run association between Brent Oil and WTI Oil.

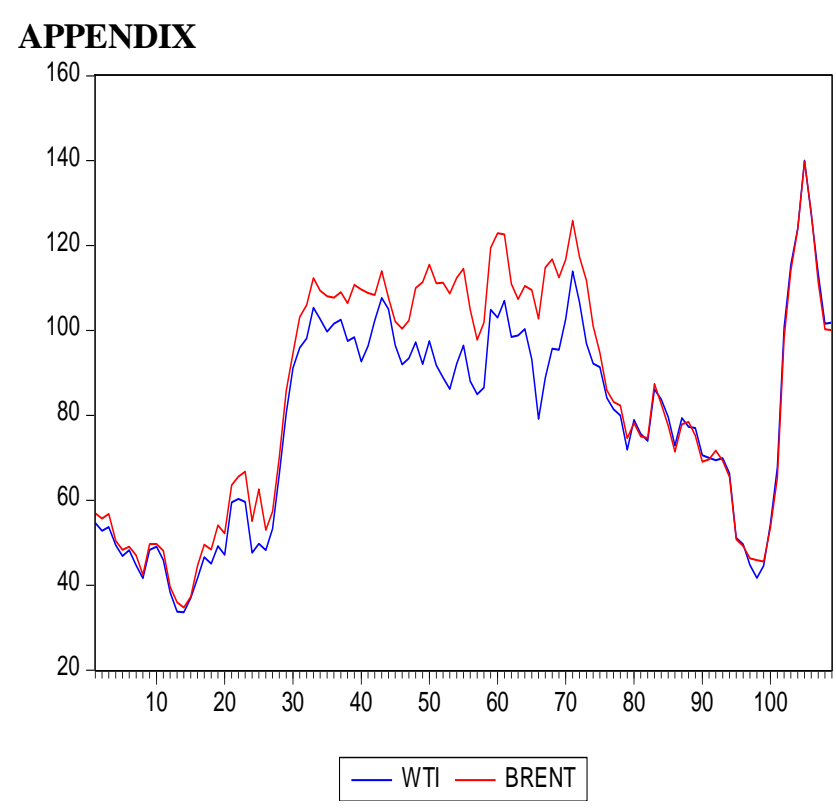

FIGURE 2: TIME SERIES GRAPH OF WTI AND BRENT 


\begin{tabular}{|l|l|l|}
\hline & \multicolumn{1}{|c|}{ WTI } & BRENT \\
\hline Mean & 78.98688 & 85.24321 \\
\hline Median & 84.11000 & 87.44000 \\
\hline Maximum & 140.0000 & 139.8300 \\
\hline Minimum & 33.62000 & 34.74000 \\
\hline Std. Dev. & 24.26418 & 27.60132 \\
\hline & -0.15079 & -0.20864 \\
Skewness & 6 & 3 \\
\hline Kurtosis & 2.071513 & 1.652532 \\
\hline Jarque-Bera & 4.328423 & 9.036996 \\
\hline Probability & 0.114840 & 0.010905 \\
\hline Sum & 8609.570 & 9291.510 \\
\hline $\begin{array}{l}\text { Sum Sq. } \\
\text { Dev. }\end{array}$ & 63585.05 & 82277.93 \\
\hline Observations & 109 & 109 \\
\hline
\end{tabular}

TABLE 1: DESCRIPTIVE STATISTICS OF WTI AND BRENT

\begin{tabular}{|c|c|c|c|c|}
\hline Series & Level & P Value & Null & Conclusion \\
\hline Brent & Base & 0.2040 & $\begin{array}{l}\text { Fail to } \\
\text { Reject }\end{array}$ & $\begin{array}{c}\text { Non } \\
\text { Stationary }\end{array}$ \\
\hline Brent & $\begin{array}{c}1^{\text {st }} \\
\text { Difference }\end{array}$ & 0.0000 & $\begin{array}{l}\text { Fail to } \\
\text { Reject }\end{array}$ & Stationary \\
\hline WTI & Base & 0.1479 & $\begin{array}{l}\text { Fail to } \\
\text { Reject }\end{array}$ & $\begin{array}{c}\text { Non } \\
\text { Stationary }\end{array}$ \\
\hline
\end{tabular}

\begin{tabular}{|c|c|c|c|c|}
\hline WTI & $\begin{array}{c}1^{\text {st }} \\
\text { Difference }\end{array}$ & 0.0000 & $\begin{array}{c}\text { Fail to } \\
\text { Reject }\end{array}$ & Stationary \\
\hline
\end{tabular}

TABLE 2: UNIT ROOT TESTING OF WTI AND BRENT

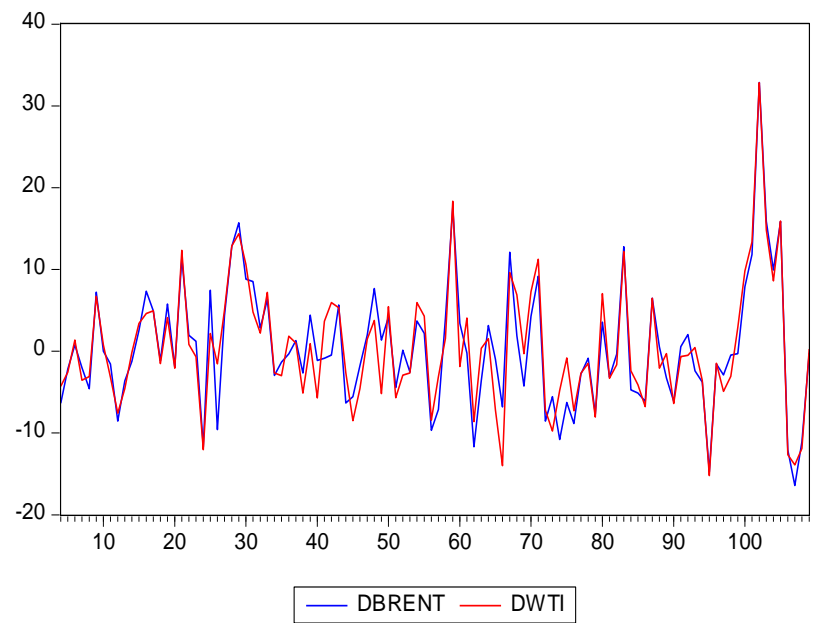

FIGURE 3: TIME SERIES GRAPH OF DWTI AND DBRENT

\begin{tabular}{|c|c|c|}
\hline & WTI & BRENT \\
\hline WTI & 1.000000 & 0.969341 \\
\hline BRENT & 0.969341 & 1.000000 \\
\hline
\end{tabular}

TABLE 3: CORRELATION BETWEEN BRENT AND WTI

\begin{tabular}{|c|c|c|c|}
\hline Null Hypothesis & Obs & F-Statistic & Prob. \\
\hline DWTI does not Granger Cause DBRENT & 106 & 0.22191 & 0.8014 \\
\hline \multicolumn{2}{|c|}{ DBRENT does not Granger Cause DWTI } & 0.26676 & 0.7664 \\
\hline
\end{tabular}

TABLE 4: PAIRWISE GRANGER CAUSALITY BETWEEN BRENT AND WTI (Lag=2)

\begin{tabular}{|c|c|c|c|c|c|}
\hline $\begin{array}{c}\text { ARDL } \\
\text { Model }\end{array}$ & AIC & SC & $\begin{array}{c}\text { Log } \\
\text { likelihood }\end{array}$ & F Wald test & $\begin{array}{c}\text { P of Wald } \\
\text { test }\end{array}$ \\
\hline ARDL(1,1) & 6.830303 & 6.955937 & -357.0060 & 15.29805 & 0.000000 \\
\hline
\end{tabular}

TABLE 5: ARDL MODEL TEST BETWEEN BRENT AND WTI

\begin{tabular}{|c|c|c|c|c|}
\hline \multicolumn{5}{|c|}{ Dependent Variable: DBRENT } \\
\hline \multicolumn{5}{|c|}{ Sample: 4109} \\
\hline \multicolumn{5}{|c|}{ Included observations: 106} \\
\hline Variable & Coefficient & Std. Error & t-Statistic & Prob. \\
\hline WTI & 0.936960 & 0.035046 & 26.73493 & 0.0000 \\
\hline WTI(-1) & -0.937350 & 0.035226 & -26.60950 & 0.0000 \\
\hline $\mathrm{R}$-squared & 0.872611 & \multicolumn{2}{|c|}{ Mean dependent var } & 0.408302 \\
\hline Adjusted R-squared & 0.871386 & \multicolumn{2}{|c|}{ S.D. dependent var } & 7.582264 \\
\hline S.E. of regression & 2.719211 & \multicolumn{2}{|c|}{ Akaike info criterion } & 4.857248 \\
\hline Sum squared resid & 768.9873 & \multirow{2}{*}{\multicolumn{2}{|c|}{ Hannan-Quinn criter. }} & 4.907502 \\
\hline Log likelihood & -255.4342 & & & 4.877616 \\
\hline Durbin-Watson stat & 1.731700 & & & \\
\hline
\end{tabular}

TABLE 6: ARDL MODEL BETWEEN BRENT AND WTI

\begin{tabular}{|c|c|c|}
\hline Residual Test & P Value & Null \\
\hline Breusch Godfrey Serial Correlation LM Test & 0.3391 & Fail to reject \\
\hline $\begin{array}{c}\text { Heteroskedasticity Test: Breusch Pagan } \\
\text { Godfrey }\end{array}$ & 0.1146 & Fail to reject \\
\hline Jarque Bera Normality Test & 0.5478 & Fail to reject \\
\hline
\end{tabular}

TABLE 7: RESIDUAL TEST BETWEEN BRENT AND WTI 


\begin{tabular}{|c|c|c|c|}
\hline Null & $\begin{array}{c}\text { Bound F } \\
\text { Test }\end{array}$ & P Value & Hypothesis \\
\hline $\begin{array}{c}\text { Coefficient of } \\
\text { WTI(-1) }=0\end{array}$ & 5.487 & 0.0211 & Rejected \\
\hline
\end{tabular}

TABLE 8: BOUND TEST FOR ARDL MODEL

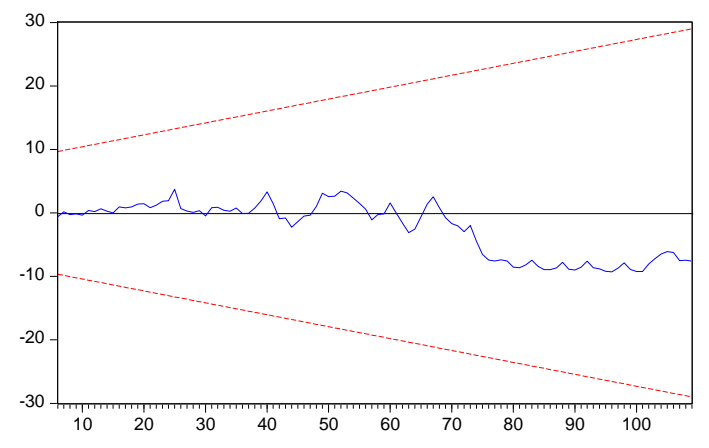

- CUSUM ---. $5 \%$ Significance

FIGURE 4: STABILITY TEST OF ARDL MODEL BETWEEN BRENT AND WTI

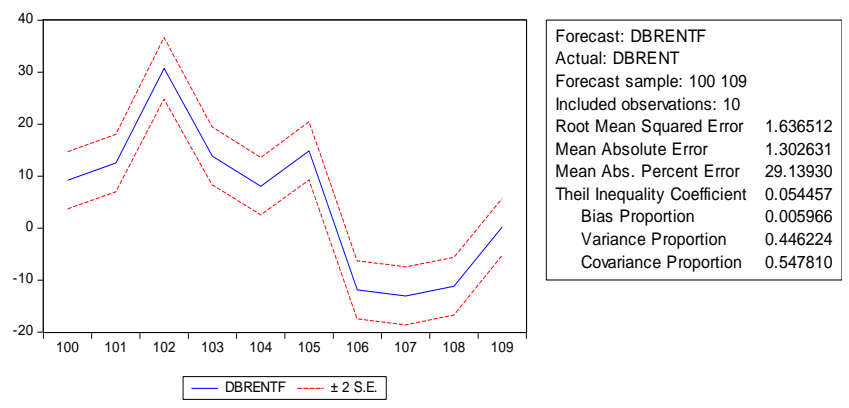

FIGURE 5: FORECASTING USING ARDL MODEL BETWEEN BRENT AND WTI

\section{REFERENCES}

1. Adelman, M.A., and G.C. Watkins (1997). The value of United States oil and gas reserves. Advances in the Economics of Energy and Resources, JAI Press Inc., 10: 131-184.

2. Chen, W., Huang, Z., \& Yi, Y. (2015). Is there a structural change in the persistence of WTI-Brent oil price spreads in the post-2010 period. Economic Modelling, 64-71.

3. Kilian, L. (2009). Not All Oil Price Shocks Are Alike: Disentangling Demand and Supply Shocks in the Crude Oil Market. American Economic Review, 99(3), 1053-1069.

4. Kilian, L. (2014). The impact of the shale oil revolution on U.S. oil and gasoline prices. Frankfurt: CFS Working Paper Series.

5. Villar, Jose, A., and Frederick L. Joutz (2006). The relationship between crude oil and natural gas prices. Energy Information Administration, Office of Oil and Gas.

6. Ramberg, David J. and John E. Parsons (2011). "The Weak Tie Between Natural Gas and Oil Prices.” CEEPR Working Paper 10-017.

7. Smith, J.L. (2004). Petroleum property valuation. Encyclopedia of Energy, Elsevier, 4: 815-816. 